KOMENTAR

\section{Traganje za dokazima o efikasnom i sigurnom lečenju}

Pri razmatranjima efektivne terapije, glavno nastojanje kliničara je usmereno na procenu efektivnosti i sigurnosti leka ili drugih terapijskih procedura. Kako lekar može biti siguran u dokaze koji se nalaze u literaturnim izvorima (knjigama i časopisima)?

"Nivo dokaza" se može uprošćeno svesti na to kako su vršena istraživanja kojima se došlo do odgovarajuće tvrdnje. Hijerahija dokaza se obično predstavlja ovim redosledom: (I) zaključci dobijeni na osnovu prikaza i analize više randomiziranih kliničkih studija (engl. "systematic review of randomized clinical trials" - RTC) i tzv. "meta-analize" su najsnažniji izvor, a slede (II) randomizirana klinička studija, (III) opservaciona studija ('cohort study', 'case-controlled study' ili 'cross-sectional survey'), (IV) prikaz slučajeva i na kraju (V) lično mišljenje autoriteta.

\section{Baze podataka}

Velika baza izvornih podataka je Medline. Ona obuhvata preko 5.000 časopisa koji izlaze u više od 70 zemalja. Besplatno je dostupna "online" na World Wide Web (WWW) putem PubMed. Ostale baze podataka su AMED, CINHAL, Current Contents, Embase, Health Star, Medicine, Premedicine, Psychinfo, ali i Google Scholar i MSN.com.

Pri traženju višeg nivoa dokaza, a posebno randomiziranih kliničkih studija i drugih kvalitetnih kliničkih ispitivanja, dobro je pored Medline i drugih izvornih baza podataka, kombinovati pretrage s "filtriranim" i "sintetisanim" bazama podataka. Primeri za prvu grupu izvora su; Cochrane Controlled Clinical Trials Register ili Evidence-Based Digests (npr. Evidence-Based Cardiology, Evidence-Based Eye Care, Evidence-Based Medicine, Evidence Based Mental Health), Health Technology Assessment Database i NHS Economic Evaluation Database, a za drugu grupu: American College of Physicians PIER, Clinical Evidence, Cochrane Database of Systematic Reviews (DARE), Database of Abstracts of Reviews of Effectiveness, EvidenceBased on Call.

Cochrane Library sadrži korisne informacije iz različitih baza podataka koje se mogu pretraživati zajedno. Zato mnogi kliničari počinju pretragu unutar Cochrane Li- brary. Ovde vredi navesti reč-dve o nazivu tog izvora. Kada je A. Cochrane bio student medicine 1938. godine, nosio je ulicama Londona plakat s natpisom: "Svi efektivni načini lečenja treba da budu besplatni." Njegova knjiga Efektivnost $i$ efikasnost ${ }^{2}$ imala je mali odjek, ali je u njoj bila suština današnje "medicine zasnovane na dokazima".

Baze podataka o citiranju članaka su takođe važan izvor informacija, jer radovi koji su citirali neki članak pokazuju potvrdu, neslaganje ili dopunu citiranog, članka. Traganje o citiranju nekog članka je moguće od ranih šezdesetih godina prošlog veka, kada je Eugene Garfield osnovao Institute for Scientific Information. Najpre je publikovan Science Citation Index (SCI), zatim Social Science Citation Index (SSCI) i Arts and Humanities Citation Index (AHCI). Kasnije je nastala elektronska verzija za traženje citiranosti, Web of Science, koja uključuje SCI, SSCI i AHCI. Noviji indeksi citiranja su OVID Medline citation track function i Scopus, kojim se pretražuju časopisi, patenti, Web podaci i praćenje citiranosti.

Kada će prezauzet lekar praktičar tražiti ove podatke? Traganje za dokazima o efikasnosti i sigurnosti lečenja on obično traži kada naiđe na neki problem u praksi i želi da se o njemu obavesti kako bi eventualno planirao svoje istraživanje, drugim rečima, kada planira istraživački projekat. Pored toga, lekar ponekad želi da proveri da li vredi uvesti nov, drugačiji terapijski postupak ili prihvatiti Preporuku o lečenju koju je primio od nekog stručnog tela. Međutim, za seriju terapijskih inovacija, lekar obično koristi moderne priručnike, ${ }^{3}$ poput ovih koji su prikazani u ovom broju našeg časopisa u rubrici "Prikazi knjiga" ili vodiča koje izdaju lekarska društva ili ministarstva zdravlja ${ }^{4}$. Saveti koji se nalaze u takvom priručniku imaju za cilj da se postojeće "filtrirano znanje", tj. dokazi o efikasnosti i sigurnosti lečenja iznesu od strane eksperta, kako bi bili široko diseminirani i lako dostupni. Zato je i džepno izdanje ovakvih knjiga primereno toj svrsi.

Lekarima se često daju farmakoterapijske preopruke. Njih pišu eksperti za razna područja medicine ispred raznih sekcija lekarskih društava, osguravajućih društava, državnih organa, međunarodnih stručnih organizacija, Svetske zdravstvene organizacije itd. Te preopruke mogu biti veoma korisne, ali ih uvek treba kritički usvajati. ${ }^{3}$

\section{Odnosi sa firmama}

Farmaceutska industrija je veoma zainteresovana da utiče na lekare, pa čak i pacijente, da se lekovi koje oni proizvode koriste što više. Ne žale se značajna novčana sredstva da se lek reklamira. Najefektivniji način kojim se postiže promena propisivačke navike kliničara je lični kontakt saradnika farmaceutske firme s lekarom. Saradnik putuje s tašnom u kojoj su "dokazi" da taj lek ima prednost nad drugima. ${ }^{4}$ Najbolje je za farmaceutsku kuću da njen saradnik pokaže kontrolisanu kliničku studiju u kojoj je taj lek upoređen s placebom, a ne s nekim paralelnim lekom. "Ako je taj lek 
baš morao da se poredi s paralelnim, saradnik farmaceutske kuće obično pokaže podatke koji porede lek koji bude reklamiran s konkurentskim koji je davan u subterapijskim dozama." Neće taj saradnik saopštiti smrtne slučajeve ili teške neželjene efekte leka. On, usput, obično navede nekoliko uticajnih lokalnih lekara koji primenjuju taj lek. Bićete takođe ubeđivani da se "naš lek, mada je skuplji od konkurentskog, ipak, zbog svega drugog više isplati."

Iskusni farmakolozi savetuju lekare: ${ }^{5}$ Primite predstavnika farmaceutske kuće samo onda kada mu zakažete prijem i to uradite ako vas dotični proizvod interesuje, ne dozvolite da vam on deklamuje naučen tekst, pitajte ga ono što vas interesuje, tražite da vam pokaže nezavisne publikovane dokaze o tom leku iz poznatih časopisa, ne pridajte značaj promotivnim brošurama jer one često sadrže nepublikovane materijale, pitajte ga kakva je sigurnost tog leka, njego- va tolerancija, efikasnost, cena, a neka vas ne impresionira što je lek nov, jer to mu može biti i mana.

\section{Urednik}

\section{Reference}

1. Greenhalgh T. How to read a paper. The basis of evidence-based medicine, third edition. London: BMJ, 2006.

2. Cochrane A. Effectiveness and efficiency. London: Nuffield Provincial Hospitals Trust, 1972.

3. Kažić T. Lični stav: Preporuke i praksa. Scripta Medica, 2010;41:88-91.

4. Timovi ljekara. Klinički vodiči za primarnu zdravstvenu zaštitu. Banja Luka, Ministarstvo zdravlja i socijalne zaštite Republiek Srpske, 2004.

5. Anonymous. Getting good value from drug reps. Drug Ther Bull 1983;21:13-5. 